\title{
Formation of Apprenticeships in the Swedish Education System: Different Stakeholder Perspectives
}

\author{
Ingela Andersson* \\ University of Gothenburg \\ Faculty of Education \\ Västra Hamngatan 25, 40530 Gothenburg, Sweden \\ E-mail: ingela.andersson@gu.se \\ Gun-Britt Wärvik \\ University of Gothenburg \\ Faculty of Education \\ Västra Hamngatan 25, 40530 Gothenburg, Sweden \\ E-mail: gun-britt.warvik@ped.gu.se

\section{Per-Olof Thång} \\ University of Gothenburg \\ Faculty of Education \\ Västra Hamngatan 25, 40530 Gothenburg, Sweden \\ E-mail: per-olof.thang@ped.gu.se \\ * Corresponding author
}

\begin{abstract}
The article explores the major features of the Swedish Government's new initiative - a school based Upper Secondary Apprenticeship model. The analyses are guided by activity theory. The analysed texts are part of the parliamentary reformmaking process of the 2011 Upper Secondary School reform. The analyses unfold how the Government, the Swedish Trade Union Confederation (LO), and the Confederation of Swedish Enterprise (SN) construct Upper Secondary Apprenticeship as an activity in the 21 st century. The conclusion highlights how three traditional aspects of Swedish initial vocational education and training (IVET) collide in the formation of Upper Secondary Apprenticeship - a curriculum of labour market based apprenticeships, a curriculum of school based IVET, and ill-defined curriculums of school based apprenticeships. The emerging Upper Secondary Apprenticeship curriculum foreshadows multifaceted educational trajectories where the learning targets, and not the responsibility for the student's learning are displaced from the school to the workplace setting.
\end{abstract}

Keywords: initial vocational education and training, school-based apprenticeships, policy formation, activity theory, educational trajectories, upper secondary school 


\section{Bibliographical notes:}

Ingela Andersson is a $\mathrm{PhD}$ student at the Department of Education and Special Education at the University of Gothenburg. Her research interests focus on VET policy, and curriculum work in the interface between school and workplaces.

Dr Gun-Britt Wärvik is an associate professor at the Department of Education and Special Education at the University of Gothenburg. Her research interests focus on politics of education, including vocational education and training and adult learning.

Dr Per-Olof Thång is a professor at the Department of Education and Special Education at the University of Gothenburg. His research interests focus on adult education, learning at work and vocational education. 


\section{Introduction}

In recent years vocational education and training (VET) systems in many countries have been reformed in an effort to comply with societal demands (Deissinger et al., 2011; Fuller and Unwin, 2009; Juul and Jörgensen, 2011; Nilsson, 2010; Olofsson, 2014; Paine, 2002; Steedman, 2012). These demands concern how to design training programmes that qualify for work. Hence, VET programmes that contribute to provide a skilled workforce, and that promote high employment rates are important for the national economy and social welfare. Therefor, political reasons behind VET reforms are also to prevent youth unemployment and school dropout. In 2011 the Swedish government launched their new initiative, "Upper Secondary Apprenticeship", as a parallel to the school situated initial vocational education and training (IVET) programmes. The aim of this article is to analyse the preceding modelling process of the new Upper Secondary Apprenticeship initiative, and the dynamics of a new IVET curriculum. Despite being a new initiative, apprenticeships emphasise educational trajectories inhabited by traditions at the labour market, and in the state governed Upper Secondary IVET system. Our point of departure is thus that educational change never is a straightforward process (Engeström, 2009). It unfolds in a tension-laden interplay between different stakeholder perspectives, e.g. efforts to resist or comply with evolving demands. The change effort is driven by societal motives (Engeström, 1987; 2010). In education this motive is often concerned with providing alternative educational trajectories for different students. However, apprenticeship trajectories that lead to early occupational specialisation may not be the obvious solution for the young upper secondary students (Lundahl et al., 2010; Nylund, 2013). Many occupational areas require a broad general training base that prepare for further education. Therefor, in addition to the government's position on how IVET policy could be realised, we argue that the different positions of the labour market parties are required to contribute to the understanding of what is referred to as apprenticeship in Upper Secondary School, and the value it holds as an IVET model in the first decades of the $21^{\text {st }}$ century. In the article we thus emphasise the positions of the two major labour market organisations, the Swedish Trade Union Confederation (LO) ${ }^{1}$ and the Confederation of Swedish Enterprise $(\mathrm{SN})^{2}$.

A closer examination of different labour market representatives' responses to the suggested Upper Secondary Apprenticeship curriculum also showed that they took different stands: Among those who clearly rejected the idea were the organisations that represent occupations in the electricity and energy sectors ${ }^{3}$. Apprenticeships aiming at professional drivers were out of the question in the

1 LO is the Swedish national trade union organisation that represents a wide range of employees who are members of different trade unions. In the IVET policy debate that precede the upper secondary school reform LO appear as a community that speaks for their member associations in different industries.

$2 \mathrm{SN}$ is the Swedish national organisation that represents employers in different industries. In the IVET policy debate they appear as a community, and they promote the interests of a wide range of employers' associations.

3 The Professional Board for the Electricity Industry is collaboration between Electrical Installers Association (EIO) and the Swedish Electrician Union that work to influence decision makers, and to secure education quality. Swedish Energy is a trade association with about 380 member companies. 
transportation sector ${ }^{4}$. Organisations representing industry-oriented occupations expressed clearly that they "see no need for apprenticeships" (The Swedish Industrial Employers), except in areas that demand proficiency training - as did the Swedish Food Federation. Other labour market representatives ${ }^{5}$ were however in favour of apprenticeship training schemes as an alternative, e.g. as an option, a school based training model guided by the same curriculum as the school-situated IVET programmes. Among those who advocated apprenticeship as a favourable learning model were The Entrepreneurs. This organisation represent more than 70 000 business owners in different industries, and has since long called for a modern apprenticeship alternative in upper secondary school. Similarly, the Swedish Craft and Small Business Association emphasised its significance to bring craft skills on to the next generation. Despite the various positions, the common determiner for Upper Secondary Apprenticeships was the school-based characteristics. Consequently, in most cases $^{6}$ the labour market representatives rejected the government's suggestion to offer Upper Secondary Apprenticeships as a combination of education and employment. Thus, the representatives of the different industries make a clear distinction between unpaid youth education, and paid employment ${ }^{7}$.

To summarise, what we are dealing with here is a politically propelled apprenticeship initiative that forms a marginal part of the Swedish IVET system. However, to consolidate this education model, the government made investments in a preceding pilot project between 2008-2011(SFS ${ }^{8}$ 2007:1349; SOU $^{9}$ 2011:72). Continuously through the succeeding implementation period, educators were supported both financially, and with advice from the Swedish National Agency for Education. Despite these efforts, the apprenticeship initiative has not been a success (Skolinspektionen, 2013). Schools hesitate to provide apprenticeships, and the number of participating students is much lower than expected. The number of schools organising apprenticeships totalled 170 in the spring semester, 2012. The

4 The Swedish Transport Agency draws up regulations, and work to ensure high quality, security and environmental awareness for all kinds of transportations.

5 The Professional Board for Occupations within Building and Construction and The Education Council for Hotels and Restaurants work with education and professional development for the different sectors. The Municipal Worker Union is the largest trade union representing more than 500.0000 workers in municipalities and counties. The Swedish Trade Federation is an employers association that represent commercial enterprises in the entire trade and commerce sector.

6 The Swedish Craft and Small Business Association emphasised employment towards the end of the three-year Upper Secondary education in their response a Committee Report (SOU 2010:19). In contrast the municipalities, from the perspective of educators, have a more positive attitude to apprenticeship as employment. Some municipalities advocate that workplaces should take a greater responsibility for the students in IVET.

7 The government suggested that upper secondary apprenticeships should be possible to offer as a combination of employment and education. The question of employment faced opposition from professional boards, employers 'and workers' organizations. Eventually apprenticeship as employment was implemented as an option in July 2014 in a separate statutory framework (Prop. 2013/14:80; SFS 2014:421).

8 The Swedish Code of Statutes (SFS) are official publications of laws enacted by the Swedish Parliament and issued by the Government.

9 Committee Reports are proposals and reports, submitted by a commission of enquiry that was appointed by the Government. These reports are then published in the Swedish Government Official Report Series (SOU). 
number of first year apprentices during the academic year 2011/12 totalled 2.265 out of the 36.850 IVET students ${ }^{10}$ (Skolverket, 2012, 2013 and 2013a). In addition, LO and $\mathrm{SN}$ have been reluctant in their responses to this governmental initiative. A puzzling question now asserts itself: Why are they hesitating? Hence, the driving question of the article concerns how we can understand the hesitating attitudes from LO and SN, e.g. how these attitudes, embedded in the VET traditions, may or may not be significant to the realisation of Upper Secondary Apprenticeships.

The article is organised as follows: In section two, some basic structures for apprenticeship as an internationally recognised learning model of the $21^{\text {st }}$ century are identified. In this context, the guiding principles for the Swedish initiative are discussed. In section three we review research on the Swedish IVET tradition, and apprenticeship. In section four we present the empirical material, and the theoretical concept of contradictions that guides the analysis. In section five the tension-laden interplay that underpins the apprenticeship initiative, and the conflicting positions are analysed. In the conclusion, we discuss the different perspectives on the 2011 apprenticeship initiative in light of the dynamics embedded in the notion of apprenticeship, and the Swedish IVET tradition.

\section{Apprenticeship - an education form with many faces}

All over the western world, apprenticeship is stressed as a successful model to develop occupational skills in the $21^{\text {st }}$ century (Fuller and Unwin, 2011). Apprenticeships, when successful, support individual development (Lave and Wenger, 1991; Tanggaard, 2007; Wenger, 1998), offer access to everyday work experiences as well as up to date knowledge (e.g. Billett, 2014), and they facilitate pathways for young people to enter the labour market (Olofsson and Panican, 2012). However, as Ryan (2000) points out, apprenticeship can be hard to define due to differences in the line of organisation. Apprenticeship:

"generally denotes a formal, structured programme of vocational preparation, sponsored by an employer, that juxtaposes part-time off-the-job instruction with on-the-job training and work experience, leads to recognised vocational qualification at craft or higher levels, and takes at least two years to complete" (p. 44).

What Ryan (2000) suggests is a broad, and general definition that includes some key features. It emphasises a combination of employment and education. Hence, there is an education provider apart from the work place that organises supplementary education and training. The definition above implies the necessity of different learning environments, such as a school and a workplace, and learning outcomes, which lead to a vocational qualification confirmed by a final certificate. Starting from this wide definition, apprenticeship may thus address different education programmes at different levels in a national education system.

As part of the Swedish national education system Upper Secondary Apprenticeship addresses young people who passed the admission requirements in elementary school, e.g. students between the age of 16 and 19. For older students from the age of 20, the complementary adult education system offers different forms of IVET in a separate framework, including adult apprenticeships. In

10 In addition, 65.650 students started an academic Upper Secondary education programme 2011/12. 
contrast, IVET models in other countries, for instance Denmark, do not make this division between youth, and adult apprentices in their organisation (Olofsson and Panican, 2008).

As anticipated, Upper Secondary Apprenticeship is included in the cohesive upper secondary school system where the 12 IVET programmes, and the six academic education programmes reside. The apprentice-student is the educator's responsibility. Within this framework, education plans may be designed based on the student's needs, and the workplaces' preconditions. According to the Committee Reports (SOU 2008:27; SOU 2010:19) one student may have the skills acquired to fulfil a vocational exam within the school-situated IVET model, whereas another student may be aided by the workplace context. Apprenticeships are thus created as an additional pathway to a vocational exam parallel to its school situated counterpart. For instance, they share the same overarching training schemes, and the same options of vocational learning targets for the different occupational outputs.

What singles out apprenticeships from the school-situated pathway is that they should primarily be performed at one or more workplaces (SFS 2010:800) ${ }^{11}$. The workplace thus becomes involved as an essential arena for learning during the three-year training period. As a consequence, increased cooperation between schools and workplaces is demanded. The statutory framework also defines this objective, which is mediated by a three-party education agreement, and collaborative IVET programme councils at the national, and the local levels (SFS 2010:800).

In contrast to IVET models in other countries the Swedish trade branches have limited influence in the organisation of Upper Secondary IVET. In Sweden, vocational learning has historically evolved from a matter for the guilds to a concern in different occupational fields, and eventually as the government's responsibility in the public education system (c.f. Nilsson, 2013 a; Nilsson, 1981; Olofsson and Wadensjö, 2011). In addition, an apprenticeship act was never introduced. In this context, apprenticeships instead evolved as employment, and as part of the different agreements on the labour market, whereas the dominating IVET model became school based (Lundahl, 1997; Nilsson, 2013 b; Olofsson and Wadensjö, 2011). This development may shed light on the difference between the Danish and the Swedish traditions to arrange IVET e.g. why the different Swedish industries, and crafts take a less active part in the publicly organised IVET. For example, they do not take a prominent part in the final assessment for the exams. Hence, a journeyman letters, or vocational qualification tests are not included in Upper Secondary

11 The meaning of primarily performed at one or more workplaces is unclear. A complete three-year upper secondary vocational exam contains 2.500 education credits divided in mostly 100 credit courses. This statutory framework applies to all 12 IVET programmes regardless of whether the student participates in the school situated, or the apprenticeship pathway. The apprenticeship pathway as primarily performed at workplaces seems to refer to time spent at the workplace, rather than educational content or learning aims. However, these aims are to be described in the related threeparty agreement. According to the Education Act (SFS 2010:800) apprenticeship can begin the first, second or third year. From the time the student starts apprenticeship it shall primarily be performed at one or more workplaces. For the school situated counterpart the statutory framework prescribes workplace-situated learning as part of all IVET programmes, and the Swedish National Agency for Education provides the guidelines e.g. at least 15 weeks during the three years. 
Apprenticeships. Instead the school issues the vocational exam in the form of a leaving certificate based on the coursework ${ }^{12}$.

A brief comparison to the Danish, and the Norwegian youth education models may be helpful to distinguish what is formally referred to as Upper Secondary Apprenticeship in Sweden. In Denmark, the dual system offers an apprenticeship model influenced by a long tradition of cooperation between the government, and the labour market parties. Different industries and professional associations have an extensive responsibility for planning, and carrying out apprenticeships (Helms Jørgensen 2008). As for the Norwegian model, apprenticeships within different trades has been incorporated in the cohesive school based education system (Olsen et al., 2008). In Sweden IVET became school-based in the 1970's. In 2011 Upper Secondary Apprenticeships were introduced, and a large part of the education became relocated to the workplace. In table 1 the components discussed in this section are outlined for the three models.

Table 1: Basic structures of IVET - Apprenticeship in Denmark, Norway and Sweden

\begin{tabular}{|c|c|c|c|}
\hline & Denmark & Norway & Sweden \\
\hline & 3 years & $2+2$ years & 3 years \\
\hline Characteristics & $\begin{array}{l}\text { Alternating be- } \\
\text { tween workplace } \\
\text { and school. Start- } \\
\text { ing with school } \\
\text { based preparatory } \\
\text { education }\end{array}$ & $\begin{array}{l}\text { Two years of } \\
\text { school based pre- } \\
\text { paration followed } \\
\text { by a two-year } \\
\text { apprenticeship }\end{array}$ & $\begin{array}{l}\text { Preliminary per- } \\
\text { formed at one or } \\
\text { more work places }\end{array}$ \\
\hline $\begin{array}{l}\text { Apprenticeship } \\
\text { as dominating } \\
\text { IVET model }\end{array}$ & Yes & Yes & No \\
\hline School form & $\begin{array}{l}\text { Independent Vo- } \\
\text { cational Colleges }\end{array}$ & $\begin{array}{l}\text { Integrated in Upper } \\
\text { Secondary School }\end{array}$ & $\begin{array}{l}\text { Integrated in Upper } \\
\text { Secondary School }\end{array}$ \\
\hline $\begin{array}{l}\text { Eligibility to } \\
\text { higher education }\end{array}$ & Optional & Optional & Optional \\
\hline Age restriction & -- & |- & Yes, 19 \\
\hline Vocational exam & $\begin{array}{l}\text { Vocational exami- } \\
\text { nations validated } \\
\text { by the craft and } \\
\text { trade branches } \\
\end{array}$ & $\begin{array}{l}\text { Vocational exa- } \\
\text { minations valida- } \\
\text { ted by the craft and } \\
\text { trade branches }\end{array}$ & $\begin{array}{l}\text { Vocational exam } \\
\text { based on the } \\
\text { coursework is issued } \\
\text { by the school }\end{array}$ \\
\hline Employment & Yes & Yes & $\begin{array}{lll}\text { Optional since July } \\
2014^{1}\end{array}$ \\
\hline
\end{tabular}

12 The vocational exam or diploma requires that the student has received the grade passed in 2.250 out of the 2.500 course credits that constitutes each of the 12 IVET programmes. The programmes are: Building and Construction, Business and Administration, Child and Recreation, Electricity and Energy, Handicraft, Health and Social Care, Hotel and Tourism, HVAC and Property Maintenance, Industrial Technology, Natural Resource Use, Restaurant Management and Food, Vehicle and Transport. For the exam the grade passed is required in Swedish or Swedish as a second language 100 credits, English 100 credits, Mathematics 100 credits, subjects common to the programme 400 credits, and in the vocational diploma project 100 credits. 


\section{Research on apprenticeships in the Swedish IVET tradition}

Research on the features and dynamics of IVET in the Swedish society are found in different scientific fields. This body of knowledge offers insight into the Swedish IVET system, its curriculum, its historical development, and its importance for social and economic growth. In brief, researchers who take a critical stand to education policy focus on the contemporary formation of IVET policy, and change (Carlbaum, 2012; Lundahl et al., 2010; Nylund, 2013). In the field of pedagogy, there are also document analyses that scrutinize the historical formation of the Swedish IVET system during the $20^{\text {th }}$ century (Broberg, 2014; Hedman, 2001; Nilsson, 1981). Research in the fields of sociology, and economic history bring together IVET, apprenticeships, and the relation to labour market issues (Olofsson, 2014; Olofsson, 2005; Olofsson and Panican, 2008 and 2012; Olofsson and Wadensjö, 2006 and 2011). They also address questions concerning IVET, young peoples' social conditions, and employment (Nilsson, 2010; Olofsson et al., 2010; Panican (Ed.), 2014). These studies scrutinize for example to which extent the education system supports individual, and societal development. Eventually, Lisbeth Lundahl (1997) has made a thorough scrutiny of the social partners', LO's and The Swedish Employers' Federation's $\left(\mathrm{SAF}^{13}\right)$, involvement in questions that concern education policy in the period between world war two and the 1990ies.

In this section we outline the dynamics of apprenticeships as part of the labour market agreements, and as part of the state governed Swedish IVET system. From the various research perspectives we identify and elaborate on three cultural and historical turning points. These turning points constitute landmarks for when what is referred to as apprenticeship is brought to a head: The first decades of the $20^{\text {th }}$ century, the 1950's, and the 1980's.

\subsection{The first decades of the 20th century}

The 1918 Practical Youth School Reform has been identified as a turning point, and as the birth of the state governed IVET system (Hedman, 2001; Nilsson, 1981). This reform introduced Apprenticeship School and Vocational School. In addition, in 1921 the Workshop School was introduced. Before, apprenticeships within the different crafts constituted the model for vocational learning in Swedish society. Now, the government took an interest in IVET as a means to govern societal growth, and school-based elements of vocational training were added to the labour market based apprenticeships. This interest was on the one hand evoked by technical innovations, which demanded theoretical knowledge besides the manual skills. On the other hand, adolescents created disturbance on the streets, and even though these youngsters had completed compulsory school, they were still too young to be employed by industry (Nilsson, 1981). Hence, civic education was demanded. The IVET questions thus concerned socio-economic matters that engaged both the political establishment, and the social partners. However, as Olofsson (2005) points out, in contrast to other countries, e.g. Germany and Austria, Sweden did not choose a general statutory framework for apprenticeship that included expanded schooling. SAF was against such legislations as was LO (Lundahl, 1997). Instead they protected the delineation between school and work. They preserved apprenticeships as workplace based parts of the education - as a labour market based IVET curriculum.

13 In 2001 SAF and the Industrial Employers joint and formed the Confederation of Swedish Enterprise (SN). 
Apprenticeships that fostered occupational skills thus remained the labour market's responsibility, whereas the government took care of the complementary education in the school (Hedman, 2001; Nilsson, 1981). In this context, workplace based education was the primary activity of the apprenticeship schools, and as such it was still organised separately as employment (Olofsson, 2005).

To conclude, the Apprenticeship School of the 1918 reform entailed a double motive where one part, school, concerned civic skills, and another part, apprenticeship, concerned specific occupational skills developed through work. Apprenticeship became manifested as a labour market based IVET curriculum. These early IVET models aimed at three sectors, craft and industry, commerce and office work, and domestic work.

\subsection{The 1950's}

In the 1950's, the IVET questions came to concern how to design education models for the different sectors. Now, the labour market governed apprenticeships were held back. Instead, a school based IVET curriculum emerged in the tension that arose when the demand for labour heavily increased in the manufacturing industry and in the public service sector (Broberg, 2014; Lundahl, 1997; Nilsson, 2013b). In this context, the work-integrated learning model e.g. the labour market based apprenticeship curriculums were criticized as being low quality. One argument concerned a mismatch. Instead of offering adequate theoretical knowledge and practical training, apprenticeships offered occupational skills useful only to the company at hand (Olofsson, 2005). Consequently, the labour market based apprenticeships were of less interest to the government since these could not support the training demands in a rapidly growing economy. The idea was nevertheless not abandoned. Both LO and SAF supported, and promoted the development of apprenticeships within the different occupational sectors (Lundahl, 1997). Apprenticeship therefor remained as a learning model - negotiated and regulated as employment within the different sectors - however mostly as a matter for the handicrafts, and smaller enterprises (Nilsson, 2013b). On the one hand then, both LO and SAF demarcated apprenticeships' position as part of the labour market agreements, and not as the government's concern. On the other hand, both organisations also supported the government's interest in VET, and advocated the Vocational Schools, and the Workshop Schools (Lundahl, 1997). Moreover, as the young people turned their back on apprenticeships, the school based VET models expanded (Olofsson, 2005). Consequently, an IVET curriculum that included teaching and tutoring in general subjects and vocational theory, as well as proficiency training that prepared for work was manifested. Since the Workshop School included production the vocational teacher served as both foreman and supervisor. The students thus, similarly to apprentices, worked with assignments that held a value on the market (Broberg, 2014). However, in contrast to apprenticeships where learning and labour were closely related, learning in Workshop Schools became the outcome of taking part in an educational setting that produced goods and services.

To conclude, it is reasonable to state that the Swedish tradition supports a clear division between school and work. In the 1950's then, through the evolving interest in state funded schooling, IVET was split in different directions. Work-integrated apprenticeships were put up against the workshop situated VET alternatives. As a result, a school based IVET curriculum was established as a concern for both the 
government and the social partners whereas the labour market based apprenticeship curriculum remained the labour market's concern.

\subsection{The 1980's}

In the 1980's the IVET questions no longer concerned apprenticeships, instead young people were expected to complete upper secondary education to obtain the basic and generic skills demanded in society. In this context, the social partners' different standpoints were brought to the light as the socio-economic and labourrelated arguments had increased on their agendas (Lundahl, 1997). LO, on the one hand, advocated Upper Secondary School as a means to reach a high, and equal education level. People with low educational outcomes were considered at risk of unemployment and social exclusion. The motive that manifested LO's interest in Upper Secondary IVET thus focused on strengthening individuals' position in society: SAF, on the other hand, questioned the economic value of school situated IVET, and specified their demands. According to them the IVET system was to produce qualified workers with a broad educational base, and with skills such as adaptability and problem solving. As Lundahl (1997) points out, a reoccurring theme at SAF's congresses during the 1980ies was to "foster the youth to entrepreneurial spirit" (p. 250). However, neither apprenticeships, nor the school based IVET programmes corresponded to the demands from the large-scale industries, which still employed a majority of the workforce (Lundahl, 1997). The school situated Upper Secondary IVET curriculum that was consolidated in the early1970ies was now criticized for the lack of labour market relevance, and the idea of apprenticeship was disregarded as an expensive and time-consuming solution that took at least three to four years to complete. Accordingly, the IVET questions now concerned what knowledge and skills the schools should provide in order to secure the students' labour market entry, and social inclusion.

In a totally different guise then, the government revived the concept of apprenticeship, and ill-defined school based apprenticeship curriculums appear. Different apprenticeship projects were now introduced in the organisation of school based Upper Secondary IVET (Olofsson and Wadensjö, 2006 and 2011). These projects were not mainly in the interest of the labour market parties. The guiding principle was instead the government's interest to secure education at upper secondary level for all young people in a youth cohort (Carlbaum, 2012; Lundahl et al., 2010; Nylund, 2013). The various trials with apprenticeships can thus be understood as attempts to reconstruct an IVET model in Upper Secondary School through increased differentiation e.g. by offering more educational alternatives in a time when more and more young people were expected to undergo upper secondary education. The IVET questions that concerned apprenticeships now became about how to meet, and match students' needs. Apprenticeships were thus neither reconstructed as the general IVET model, nor as a collaborative activity between the government and the labour market parties. One attempt focused on apprenticeship with joint responsibility between school, and workplace, which existed for a small number of students in the 1980's, mainly within building and construction (Olofsson and Wadensjö, 2006).

In the early 1990's, apprenticeships appeared as alternatives within individual programme ${ }^{14}$. In addition, a pilot project aiming to introduce Upper Secondary

14 The individual programme (IP) was an education form for students that, for various reasons, lacked compulsory school proficiency. This programme provided an educa- 
Apprenticeships within the school system was implemented in the late 1990's. It included collaboration strategies between schools and work e.g. a three-party contract, and programme councils with influence on education content and work placement (Olofsson and Wadensjö, 2006). These projects are examples of school based attempts to merge school and work through apprenticeships that did not succeed.

To conclude, through the 1970 upper secondary education reform, the government consolidated a school based IVET curriculum. In addition scattered and ill-defined school based apprenticeship curriculums were manifested in attempts to implement school-based apprenticeships between the 1980's and 2000. These attempts both attracted and addressed specific target groups, e.g. craft trades such as building and construction, and as special education arrangements for young students at risk of falling out of the education system. In addition, the social partners, $\mathrm{LO}$ and SAF, were neither given, nor did they claim any influence in these projects.

\section{Method}

The following analysis concerns the process and arrangements of the Swedish Upper Secondary Apprenticeship model. A Government report was sent for consultation to (among others) the labour market organisations that were invited to submit their views on the proposed initiative. The empirical material consisted of texts written by the Government, and the responses written by the Swedish Trade Union Confederation (LO), and the Confederation of Swedish Enterprise (SN). These responses to the reform suggestions provide rich sources to develop understanding about the controversial nature of the apprenticeship reform. Hence, an argument for this analysis is that the labour market perspectives add another dimension. In addition to the government's perspective that is scrutinized in the critical policy analyses (Carlbaum, 2012; Lundahl et al., 2010; Nylund, 2013), LO's and SN's perspectives are important since these organizations have had great influence on the formation of vocational education since the post war period (Lundahl, 1997). All together the texts are part of a process initiated and managed by the Government. Thus, what we are dealing with here is a snapshot of a reform making process, discursive in nature, intended to influence the outcome of the reform.

The analysed excerpts derive from the parliamentary process and consist of Committee Directives, Committee Reports, Government Bills, and LO's and SN's responses to the Committee Reports. Figure 1 illustrates the parliamentary process where education policy and the statutory framework for Upper Secondary Apprenticeship is formulated, including where in the process the referral procedure takes place.

tional pathway preparing for them entry to a national Upper Secondary programme. IP was included in the upper secondary school organisation. 
Committee Directive issued by The Department of Education

1. "A Reformed Upper Secondary School” (Dir 2007:8)

2. "Apprenticeship Employment” (Dir 2009:70)

Committee Report investigates and gives suggestions

1. The Future Pathway - A reformed Upper Secondary School (SOU 2008:27)

2. Apprenticeship - A Bridge between School and Work (SOU 2010:19)

Consultation procedure: Department of education

Stakeholders' responses

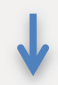

1, $2 L O-1,2 S N$

Government Bill for parliament to decide on

1. Higher Standards and Quality in the new Upper Secondary School (Prop. 2008/09:199)

2. Quality in Upper Secondary Apprenticeship (Prop. 2010/11:104)

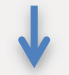

Altered legal framework

The Education Act (SFS 2010:800). The Upper Secondary School Ordinance (SFS 2010:2039)

Figure 1: The parliamentary process where the statutory framework for Upper Secondary Apprenticeship is formulated

\section{Analytical framework}

In the reform making process the government, LO and $\mathrm{SN}$ are identified as interacting activity systems that negotiate an outcome of common interest (Engeström, 1999). Activity systems are collective, culturally mediated and objectoriented formations of human activities. An activity system is an indivisible whole, composed by those who engage in the activity (subject), the motives for the activity (object), and its' mediators. The mediators are instrumental tools, but also rules, community and division of labour. Activity systems are produced by human actions at the same time as they produce actions. As they are deep-rooted both in their older sediments and their production of germs of possible futures they are robust and stable, yet they also constantly change and evolve. Thereby they are producing tensions, and contradictions between older layers and the possible new (Engeström, 1987 and 2009). In other words, activity systems are object-driven and objectproducing activities, developed in accordance with societal needs. They have a societal relevance, and contribute both to stabilise and destabilise the activities.

The discursive manifestations of conflicting dynamics as they appear in policy texts are the analytical focus of the article. From a cultural-historical perspective (Engeström, 1987) then the analysis begins with identification of the problematic expressed in the texts written by the government. The problematic reveal that according to the government the Upper Secondary IVET is not working the way it ought to. It neither matches the labour market's demands, nor do the students fit in. In the next step, responses from LO and SN to the suggested apprenticeship initiative 
are analysed. In this step we delineate linguistic manifestations of conflicts and dilemmas as indicators of contradictions (Engeström and Sannino, 2011). Yes or No followed by a reformulation of the suggestion indicates a reconstruction of the object from the perspective of a neighbouring activity. Yes or no followed by ...but indicates conflicting positions. The linguistic manifestations of conflicts and dilemmas are brought together, and regarded as manifestations of conflicting positions. In the next section the analysis reveals the dynamics embedded in the conflicting positions, and an evolving Upper Secondary Apprenticeship curriculum can be foreshadowed.

\section{The dynamics of apprenticeship as an innovation of upper secondary IVET}

From the government's standpoint, three arguments underpin the 2011 apprenticeship reform. One argument asserts that established apprenticeship models, as in Germany or Denmark, facilitates young people to enter the labour market. A second line of argumentation is the necessity of a skilled workforce, well adapted to the needs of working life. A third argument points out that some students are in need of the different learning environment that a workplace offers (Prop. 2008/09:199; Prop. 2010/11:104; Prop. 2013/14:80). In the Swedish context then, the societal problems that give rise to the need to renew the organisation of upper secondary IVET are about high youth unemployment rates, IVET programmes that do not provide adequate skills, and students that fail to complete these programmes. In this section we show how the suggested apprenticeship model derives from the societal, educational contradiction - Upper Secondary IVET does not match the labour market's demands, and the students do not pass the exams - which the government spells out in the committee directive.

"There is a shortage in educated labour in occupations where employees receive the initial training in upper secondary school. Simultaneously organised training does not qualify for work" (Dir. 2007:8 p. 4).

Here the government manifests a gap between the education system, and the labour market's demand for qualified workers. The apprenticeship initiative is emphasised as a solution, as an alternative to the school situated IVET pathway: "Upper Secondary Apprenticeship shall be inserted as an alternative path to a vocational exam within Upper Secondary IVET" (Prop. 2008/09:199 p. 64).

In the following three subsections we show how the government, LO and $\mathrm{SN}$ formulate Upper Secondary Apprenticeship as potential educational trajectories. First, we present the government's suggestion of apprenticeship as an education model in response to societal demands, e.g. as a model to fill a gap. We show how they partly displace the responsibility from the school to the workplace in order to enable students to reach an IVET exam. In the first subsection we present LO's perspective. The conflicting positions derive from their emphasis on the double assignment embedded in the state governed school system, which is in contrast to labor market based education. We show how LO emphasizes apprenticeship branches of educational trajectories, established within the framework of Upper Secondary School: As a learning model for specific circumstances, in narrow trades, in remote areas, and for students who prefer workplace-situated learning. In the second subsection we present SN's perspective. The conflicting positions arise from SN's emphasis on both IVET programmes, and academic programmes as relevant to 
the labor market demands, which is in contrast to workplace based education. We then show how SN emphasizes apprenticeship as educational trajectories in some occupational sectors, as a learning model to provide the labor market with skilled workers.

\title{
5.1 The problem for Government
}

There is a gap, a disturbance, in the school based IVET model. The government stresses that school situated Upper Secondary IVET is inadequate as a learning model, promoting Upper Secondary Apprenticeship to solve the problem.

\begin{abstract}
"Most students in elementary school continues to Upper Secondary School, but far from everyone completes the education /..../ Students who fail to reach a final degree participate above all in the vocational education and training programmes" (Dir. 2007:8 p. 2).
\end{abstract}

The students are here depicted as unfit for school, and are seen as being less capable to reach the knowledge requirements set by the school. School situated IVET is thus not an option for all students. Accordingly, apprenticeships and the workplaces are put forward as alternative settings for learning:

"Students learn in different ways. Some prefer learning in production, and workplace learning /..../ Upper Secondary Apprenticeship will be an attractive alternative for many students" (Prop. 2008/09:199 p. 65).

In this context, the existing school based IVET model is expanded with workplacesituated apprenticeships to comply with the students' needs. Consequently, an Upper Secondary Apprenticeship curriculum appears as a framework that could provide learning content that meets the demands of both the labour market and the students. We can thus assume that this curriculum is intended to fill the gap where the school system fails.

To conclude: The school's problem to offer all IVET students an education that leads to a vocational diploma is now partly displaced to the workplaces. The question of Upper Secondary Apprenticeship thus concerns how to organise, and what to include in the state governed apprenticeship initiative e.g. what to learn, where, when, for whom, and why? These questions are of importance to both LO and SN since the workplace now is intended as an expanded educational setting for many students. From their perspectives however, the workplace is approved of as an educational setting, but not under all circumstances.

\subsection{LO's responses on the innovation}

The following linguistic manifestations of conflicting positions show how LO, the Swedish Trade Union Confederation, formulate Upper Secondary Apprenticeship as one pedagogical alternative within the framework of Upper Secondary IVET. First, they position apprenticeships as equivalent to all upper secondary education offerings. Secondly, they position the workplace as an important setting for learning that corresponds to more than just the apprenticeship initiative. In other words, school based apprenticeships are acceptable, but only as pedagogical options in certain cases. 
First, in the context of the cohesive upper secondary school system, LO stresses this education level as the basis for a broad civic education, and as vocational preparation:

"LO agrees with the Committee Report that upper secondary school is important for the supply of a local and regional workforce /..../ (but) the school also have a responsibility to provide knowledge and skills for individual development, and as preparation for citizenship" (LO's response to SOU 2008:27 p. 1)

LO advocates Upper Secondary IVET as an education model that is sensitive to the local demands. However, upper secondary education is also advanced as a sociopolitical responsibility to foster all IVET students as future citizens, and not only as future entrepreneurs or workers. Apprenticeships are emphasised as part of this package:

"LO notes with satisfaction that Upper Secondary Apprenticeship ... does not differ from its school based counterparts by no more than the time spent as workplace based learning" (LO's response to SOU 2008:27 p. 5).

Hence, LO establishes apprenticeships as equivalent to the school situated IVET programmes. Here, the school and the workplace are only emphasised as different settings for learning. A fundamental issue from LO's perspective is also to maintain educational equivalence in upper secondary school:

"LO has a different opinion than the Committee Report ... all national education programmes, including apprenticeship, at upper secondary level, should include eligibility to university" (LO's response to SOU 2008:27 p.1).

By including eligibility to university in the various IVET exams, apprenticeship is thus formulated as a broad basic education model. It is intended to be oriented towards, rather than restricted to, the different occupational sectors.

Secondly, LO stresses that apprenticeships cannot be an extensive part of Upper Secondary School. Workplaces are highlighted as important educational settings for different activities:

"LO warns for optimism with regard to education quality, and an ambition for volumes $/ . .$. . Workplaces are needed, and there are already several other forms of work placements ... as measures for unemployment, labour market apprenticeships, and adult apprenticeships..." (LO's response to SOU 2010:19 p.1).

Here, Upper Secondary Apprenticeship is put forward as one of several activities that contain work place situated educational components. Instead of constituting the main track for Upper Secondary IVET, apprenticeship is emphasised as a marginal and complementary alternative to the school situated counterpart.

"Upper Secondary Apprenticeship may serve specific purposes. Among the examples given in the committee report, the apprenticeship alternative may serve small occupations, small municipalities with less educational options, and as a pedagogical alternative" (LO's response to SOU 2010:19 p. 2). 
LO thus emphasises a formation of Upper Secondary Apprenticeship as school based, for certain occasions that match the demands of students, schools, and the local labour market.

To conclude, LO approves of Upper Secondary Apprenticeship as a school based learning model in certain circumstances. They feature an Upper Secondary Apprenticeship curriculum that juxtaposes workplace-situated learning, and school situated learning. It is also clear from LO's perspective that an innovative Upper Secondary Apprenticeship curriculum should include learning content that corresponds to the labour market's demands, and yet offers the students future educational options. In other words, LO rejects apprenticeship as model for student that the school system fails to support. From LO's perspective the formation of a labour market close learning model of preparatory character can be glimpsed. They foreshadow an Upper Secondary Apprenticeship curriculum that serves the purpose to offer access to different individual learning trajectories, and to reduce the risk of dead ends in youth education.

\subsection{SN's responses on the innovation}

Similar to the comments made by LO, the following discursive manifestations of conflicting positions show how SN, the employer organisation, formulates Upper Secondary Apprenticeship as one way to meet the labour market's demand for skilled workers. To begin, they position both IVET, and academic upper secondary programmes as school based and labour market directed. Then, they position apprenticeship as workplace situated skills training for suitable occupations. In other words, school based apprenticeships yes, but only as an option when it corresponds to the demands of specific occupations.

To begin, SN stresses the importance of labour market relevance in all upper secondary education programmes, and not only as a question for the IVET programmes:

"Students in the programmes that prepare for University also needs knowledge about the labour market to be able to choose future education in order to be prepared to enter the labour market. Therefore the labour markets demands should also be reflected in these education programmes" (SN's response to SOU 2008:27 p. 3)

From SN's perspective then, the upper secondary education system is formulated as the supplier of a future workforce.

SN also emphasises that the suggested central framework for Upper Secondary IVET is too restrictive. They stress that this framework presents an obstacle with regard to the labour market's demand for qualified workers. They advocate a flexible legal framework together with more options to create different learning pathways:

"The Confederation of Swedish Enterprise considers unlike the report that /..../ the time limited framework only should be a recommendation /..../ eligibility requirements should be adjusted to each education programme $/ . \ldots /$ the National Agency for Education could decide local and individual adjustment of education content, and duration of training..."(SN's response to SOU 2008:28 p.2). 
By reformulating the suggested frameworks, SN advocates a school based Upper Secondary IVET model that is adjustable to the labour markets' demand for skilled workers. SN thus recreates both the school situated IVET model, and the apprenticeship initiative as adjustable to specific demands. Here, learning targets and statutory frameworks are tailored by local labour market conditions.

Apprenticeship in upper secondary school is also advanced as a labour market oriented option in specific cases. In this context, $\mathrm{SN}$ emphasises that the suggested apprenticeship initiative is based on a fragile organisation that do not correspond to their demand for qualified workers in a general sense:

"SN would have wanted a more comprehensive evaluation of the apprenticeship pilot project before the establishment of a permanent form for Upper Secondary Apprenticeship. We acknowledge a demand for increased workplace situated learning in certain occupations, and this work must maintain as high a quality as possible" (SN' response to SOU 2010:19 p. 2).

In the cohesive upper secondary school system then, SN formulates apprenticeship as an option for certain occupations, and thus of marginal interest for employers in general. Certain occupations indicate concern for areas that demand extensive skills training. Particularly for companies who show an interest in providing apprenticeships for specific occupational areas. As an education model, SN equates apprenticeship with its school situated counterpart, as an equally demanding option:

\footnotetext{
"The committee report also addresses how Upper Secondary Apprenticeship could support students that are uncomfortable in school... have special interests... low motivation, social problems, diagnoses /.../ SN opposes this way to emphasise Upper Secondary Apprenticeship as the main alternative for students with special needs" (SN response to SOU 2010:19 p.2).
}

The apprentice-student is here pictured as an individual that should be able to adjust to, and perform, in both the school, and the workplace setting. Consequently Apprenticeship is formulated as a school based IVET model that corresponds to employers', or specific occupations' demands for skilled workers.

To conclude this section: SN approves of the Upper Secondary Apprenticeship initiative as a school based, workplace situated learning model in areas where the workplace setting could provide the required training opportunities. SN emphasises the formation of Apprenticeship as parallel to both school situated IVET, and academic programmes in upper secondary school. These education forms all serve different purposes in preparing students for labour market entry. Hence, SN features an Upper Secondary Apprenticeship curriculum that is part of the school based upper secondary education system - an education form that comply with, and can be tailored by the demands in the specific sectors. Apprenticeship adheres to trades where an extensive part of the training demands the workplace as a setting for learning. Consequently, the apprenticeship initiative is refuted as a general alternative for students that the traditional school system cannot handle. It is also refuted in sectors, and occupations that do not require extensive proficiency training at the upper secondary level. From SN's perspective, we get a glimpse of an Upper Secondary Apprenticeship curriculum that produces skilled workers for specific occupations. 


\section{Conclusion}

The analysis has focused on the political reform making process as a means to reform the Upper Secondary IVET model. In the article we have given examples of how different perspectives on a new educational initiative may be transformed to potential outcomes. The analysis also gave a glimpse of potentially new educational trajectories. In comparison to apprenticeship models in other countries (Billett, 2014; Fuller and Unwin, 2011; Helms Jørgensen, 2008; Olsen et al., 2008; Ryan, 2000) we found that the Swedish initiative differed on several accounts. The most prominent difference was its school-based characteristics where the labour market stakeholders rejected Upper Secondary Apprenticeship as employment. Instead, the emerging school based Upper Secondary Apprenticeship model was widely, but not fully, accepted.

The discursive manifestations of conflicts and dilemmas in the Swedish policy reform making process emphasised the different perspectives. As we have shown, the government, LO, and SN took different stand in two major areas. First, the government emphasised Upper Secondary Apprenticeships as a form of employment, which was widely rejected by the labour market representatives. In contrast, both LO and SN emphasised apprenticeship as firmly based within the framework of Upper Secondary School, and as the school's and the government's responsibility. Upper Secondary Apprenticeship was thus approved of as one way to organise initial vocational education and training, and refuted as a labour market based curriculum linked directly to employment. Secondly, the government stressed Upper Secondary Apprenticeship as a viable learning model for many students. In this context LO, on the one hand, made a clarification and reformulated the suggested apprenticeship pathway as an equal alternative to the school-situated counterpart. They also advocated apprenticeships in cases where it could be regarded as a suitable option for the student, the school, and the local labour market. SN on the other hand, advocated Upper Secondary Apprenticeship for occupations that demanded proficiency training, as a model that could produce skilled workers for specific trades.

In light of the three culturally and historically evolved curriculums identified in section three - a curriculum of labour market based apprenticeships, a curriculum of school based IVET, and the ill-defined curriculums of school based apprenticeships - we can now elaborate on the complexity inhabited in the different standpoints. Upper Secondary Apprenticeship both collides and complies with the different traditions. In contrast to school based IVET, labour market based apprenticeships has traditionally been a matter for the social partners to negotiate without government intervention. A privilege they still claim as these labour market based apprenticeships were, and still are featured by employment (Lundahl, 1997; Olofsson \& Wadensjö, 2006 and 2011). As Olofsson (2005) shows, the labour market based apprenticeship were regarded as too narrow, and sometimes as only adjusted to the specific demands at one workplace. Hence, they never became included in the organisation of the cohesive upper secondary school in the 1970's. In addition, Nilsson (2013b) shows how the early forms of labour market governed apprenticeships were established as a matter for the handicrafts, whereas school based IVET evolved as a model that complied with occupations that demanded additional theoretical and manual preparation. Simultaneously, we can understand that these traditions, which include skills training at the workplace, and complementary school situated learning, are combined in the emerging Upper Secondary Apprenticeship curriculum. As such, both LO and SN formulate the new 
apprenticeships as additional educational trajectories in Upper Secondary School that can be tailored to meet different demands.

Our analysis also suggested that both LO and SN disregard the new Upper Secondary Apprenticeship initiative as a model for students that the school system failed to support. In contrast to the ill-defined apprenticeship curriculums that the government introduced in the 1980's, Upper Secondary Apprenticeship became part of the main model for IVET (Olofsson and Wadensjö, 2011). The preceding school based apprenticeship alternatives were however driven by the same motive e.g. to enable for all students to enter, and complete upper secondary education. Hence, these curriculums could be understood as answers to the government's efforts to reduce the gap between school, and work for specific target groups. Nevertheless there was one major difference manifested in the reform making process of 2011. Both LO and SN approved of school-based apprenticeship for students that so prefer, especially for those who are suited for extensive elements of workplace-based learning. In this context the apprentices were pointed out as capable students, and the workplace as a setting for vocational training. Hence, in contrast to the ill-defined school based apprenticeship curriculums that the government introduced in the 1980's the new Upper Secondary Apprenticeship curriculum indicated an evolving collaborative practice between the government and the labour market stakeholders, and between schools and workplaces.

Eventually, in addition to the critical policy analyses that focus on the Swedish Upper Secondary IVET reforms (Carlbaum, 2012; Lundahl et al., 2010), we found that the question of increased differentiation in Upper Secondary School also was manifested in the different standpoints from the labour market stakeholders. From the labour market perspective we could not, nor did we try to identify to what extent the 2011 education reform reproduces class differences, or to what extent it may support or resist social exclusion (for such analyses see Nylund, 2013; Olofsson et al., 2010). From the analysis, we could only conclude that the hesitant attitudes towards the apprenticeship initiative were rooted in a wider interest in upper secondary education. From LO's perspective the upper secondary education system is driven by the motive keep together the youth education model, and to prepare young people for active citizenship. From SN's perspective the upper secondary education system is driven by the motive to select and prepare young people for labour market entry after completing the various education programmes. From both perspectives Upper Secondary School is demarcated as a societal institution for undergraduate education rather than an institution for early vocational specialisation.

Accordingly, the analyses of conflicting positions (Engeström and Sannino, 2011) enabled us to draw together different stakeholders' perspectives on an evolving education activity without losing track of the single perspectives. These analyses are thus examples of how conflicts of interests are played out, and have been played out in Swedish society. What at first glance appeared as one educational trajectory to working life for students that did not succeed in traditional schooling, now instead emerged as multifaceted. Upper Secondary Apprenticeship foreshadows educational trajectories that point in different directions, as pedagogical alternatives, as genuine pathways to skills training at workplaces, and as conduits to working life to provide the occupational output that the schools cannot organise. These trajectories are indicated for students that fit or do not fit in Upper Secondary School, for students that have a clear occupational objective, and for students who prefer, and fit in to, workplace cultures. 


\section{References}

Billett, S. (2014). The standing of vocational education: sources of its societal esteem and implications for its enactment. Journal of Vocational Education \& Training, 66(1), 1-21.

Broberg, Å. (2014). Utbildning på gränsen mellan skola och arbete. Pedagogisk förändring i svensk yrkesutbildning 1918-1971. Dissertation: University of Stockholm.

Deissinger, T. (2011). The dominance of apprenticeships in the German VET system and its implications for Europeanization: A comparative view in the context of the EQF and the European LLL strategy. Journal of Vocational Education and Training, 63(3), 397-416.

Dir. 2007:8. En reformerad gymnasieskola. (A reformed upper secondary school) The Swedish Government's website: http://www.regeringen.se/content/1/c6/07/89/49/849e 3ffo.pdf. Accessed 9 January 2015.

Dir. 2009:70. Lärlingsanställning. (Apprenticeship employment) The Swedish Government's website: http://www.regeringen.se/sb/d/11360/a/132591. Accessed 9 January 2015.

Engeström, Y. (1987). Learning by expanding: an activity theoretical approach to developmental research. University of California, San Diego, The Laboratory of Comparative Human Cognition's website: http://lchc.ucsd.edu/mca/Paper/Engestrom/ expanding/toc.htm. Accessed 9 January 2015.

Engeström, Y. (1999). Activity theory and individual and social transformation. In Y. Engeström, R. Miettinen, \& R-L. Punamäki (Eds.), Perspectives on activity theory (pp.19-38). London: Cambridge University Press.

Engeström, Y. (2009). The future of activity theory. A rough draft. In A. Saninno, H. Daniels, \& K. D. Gutiérres (Eds.), Learning and expanding with activity theory (pp. 303-329). New York: Cambridge University Press.

Engeström, Y. (2010). Activity theory and learning at work. In M. Malloc, L. Cairns, K. Evans, \& B.N. O'Conner (Eds.), The Sage Handbook of Workplace Learning (pp 74-89). London: Sage Publications.

Engeström, Y., \& Sannino, A. (2011). Discursive manifestations of contradictions in organizational change efforts. A methodological framework. Journal of Organizational Change Management, 24(3), 368-387.

Fuller, A., \& Unwin, L. (2011). Apprenticeship as an evolving model of learning. Journal of Vocational Education \& Training, 63(3), 261-266.

Fuller, A., \& Unwin, L. (2009). Change and continuity in apprenticeship: the resilience of a model of learning. Journal of Education and Work, 22(5), 405416.

Hedman, A. (2001). I nationens och det praktiska livets tjänst. Det svenska yrkesskolesystemets tillkomst och utveckling 1918 till 1940. Dissertation: University of Umeå.

Helms Jørgensen, C. (2008). Et dansk regime for overgang fra uddannelse til arbejde? In J. Olofsson, \& A. Panican (Eds.), Ungdomars väg från skola till arbetsliv - Nordiska erfarenheter (pp. 53-130). Köpenhamn: Nordiska Ministerrådet.

Juul, I., \& Helms Jørgensen, C. (2011). Challenges for the dual system and occupational self governance in Denmark. Journal of Vocational Education and Training, 63(3), 289-303. 
LO. (2008). Framtidsvägen - en reformerad gymnasieskola SOU 2008:27. Referral response 1. D.nr. 20080264. Stockholm: The Swedish Trade Union Confederation.

LO. (2010). LOs remissvar på SOU 2010:19. Lärling - en bro mellan skola och arbetsliv. Referral response 2. D.nr. 20100456. Stockholm: The Swedish Trade Union Confederation.

Lave, J., \& Wenger, E. (1991). Situated learning. Legitimate peripheral participation. New York: Cambridge University Press.

Lundahl, L. (1997). Efter svensk modell. LO, SAF och utbildningspolitiken 1944-90. Umeå: Boréa bokförlag.

Lundahl, L., Erixon Arreman, I., Lundström, U. \& Rönnberg, L. (2010). Setting things right? Swedish upper secondary school reform in a 40-year perspective. European Journal of Education, 45(1), 46-59.

Nilsson, A. (2013a). Yrkesutbildningens utveckling 1940-1970. In P. Håkansson, \& A. Nilsson (Eds.), Yrkesutbildningens formering i Sverige 1940-1975 (pp. 2138). Lund: Nordic Academi Press.

Nilsson, A. (2013b). Lärlingsutbildning - Ett alternativ i yrkesutbildningen 19401970. In P. Håkansson, \& A. Nilsson (Eds.), Yrkesutbildningens formering $i$ Sverige 1940-1975 (pp. 87-120). Lund: Nordic Academi Press.

Nilsson, A. (2010). Vocational education and training - and engine for economic growth and a vehicle for social inclusion? Internationional Journal of Training and Development, 14(4), 251-272.

Nilsson, L. (1981). Yrkesutbildning i nutidshistoriskt perspektiv: yrkesutbildningens utveckling från skråväsendets upphörande 1846 till 1980-talet samt tankar om framtida inriktning. Dissertation: University of Gothenburg.

Nylund, M. (2013). Yrkesutbildning, klass och kunskap. En studie om sociala och politiska implikationer av innehållets organisering $i$ yrkesorienterad utbildning med fokus på 2011 års gymnasiereform. Dissertation: University of Örebro.

Olofsson, J. (2014). Yrkesutbildning i förändring - utmaningar och möjligheter ur ett forsknings och aktörsperspektiv. RATIO's website: http://ratio.se/app/uploads/2014/10/ yrkesutbildning-i-forandring.pdf. Accessed 7 January 2015.

Olofsson, J. (2005). Svensk yrkesutbildning: vägval i internationell belysning. Stockholm. SNS Förlag.

Olofsson, J. \& Panican, A. (2012). Lärlingsutbildningen - Aktuella erfarenheter och framtida möljigheter. RATIO's website: http://ratio.se/publikationer/larlingsutbildningen-aktuella-erfarenheter-och-framtida-mojligheter/. Accessed 7 January 2015.

Olofsson, J. \& Panican, A. (2008). Ungdomars etableringsförhållande i de nordiska länderna - en bakgrund. In J. Olofsson, \& A. Panican (Eds.), Ungdomars väg från skola till arbetsliv - Nordiska erfarenheter (pp. 21-52). Köpenhamn: Nordiska Ministerrådet.

Olofsson, J., Panican, A., Pettersson, L. \& Righard, E. (2010). Ungdomars övergång från skola till arbetsliv - aktuella utmaningar och lokala erfarenheter. Lunds Universitet. Lund: Media-Tryck.

Olofsson, J. \& Wadensjö, E. (2011). Lärlingsutbildning. Stockholm: SNS Förlag.

Olofsson, J. \& Wadensjö, E. (2006). Lärlingsutbildning - ett återkommande bekymmer eller en oprövad möjlighet? The Swedish Parliament's website: http://www.regeringen.se/sb/ d/108/a/72193. Accessed 7 January 2015.

Olsen, O. J., Höst, H. \& Michelsen, S. (2008). Vejer fra yrkesopplaering til arbeidsliv. 
En studie av det norske overgangsregimets effektivitet. In J. Olofsson, \& A. Panican (Eds.), Ungdomars väg från skola till arbetsliv - Nordiska erfarenheter (pp. 249-332). Köpenhamn: Nordiska Ministerrådet.

Panican, A. (Ed.). (2014). Yrkesutbildning för morgondagens arbetsliv. Stockholm: Dialogos Förslag.

Payne, J. (2002). Reconstructing apprenticeship for the twenty-first century: lessons from Norway and the UK. Research Papers in Education, 17(3), 261-292.

Prop. 2008/09:199. Högre krav och kvalitet i den nya gymnasieskolan. (Higher standards and quality in the new upper secondary school). The Swedish Parliament's website: http://www.regeringen.se/sb/d/11356/a/126461. Accessed 7 January 2015.

Prop. 2010/11:104. Kvalitet i gymnasial lärlingsutbildning. (Quality in upper secondary apprenticeships). The Swedish Parliament's website: http://www.regeringen.se/content/ 1/c6/16/43/10/6f41764c.pdf. Accessed 7 January 2015.

Prop. 2013/14:80. Gymnasial lärlingsanställning. (Upper secondary apprenticeship employment) The Swedish Parliament's website: http://www.regeringen.se/$\mathrm{sb} / \mathrm{d} / 1829$ 6/a/232917. Accessed 7 January 2015.

Ryan, P. (2000). The institutional requirements of apprenticeship: Evidence from smaller EU countries. International Journal of Training and Development, 4(1), 42-65. doi: 10.1111/1468-2419.00095.

Skolinspektionen (2013). Gymnasial lärlingsutbildning. En kvalitetsgranskning av gymnasial lärlingsutbildning. Rapport 2013:02 The School Inspectorate's website: http://www. skolinspektionen.se/Documents/Kvalitetsgranskning/larling-gy/kvalgr-larling-gy-slutrap port.pdf. Accessed 10 January_2015.

Skolverket. (2013a). Elever per programtyp och program. Rapport 395. The Swedish National Agency for Education's webwite: http://www.skolverket.se/publikationer?id =3084. Accessed 10 January 2015.

Skolverket. (2012). Redovisning av uppdrag om statsbidrag för gymnasial lärlingsutbildning och försöksverksamheten med gymnasial lärlingsutbildning läsåret 2011/12. The Swedish National Agency for Education's website: http://www.skolverket.se/ polopoly_fs/1.183097!/Menu/article/attachment/Redovisning\%20av\%20uppdrag\%20om\%20statsbidrag\%201112_120928.pd f. Accessed 9 January 2015.

Skolverket. (2013). Utvecklingen av lärlingsutbildningen. Rapport 397. The Swedish National Agency for Education's website: http://www.skolverket.se/omskolverket/publikationer/visa-enskildpublikation?_xurl_http\%3A\%2F\%2Fwww5.skolverket.se $\% 2$ Fwtpub\%2Fws $\% 2$ Fskolbok\%2Fwpubext $\% 2$ Ftrycksa k\%2FRecord\%3Fk\%3D3086. Accessed 9 January_2015.

SFS 2010:800. Skollag. (The Education Act). The Swedish Parliament's website: http://www.riksdagen.se/sv/Dokument-Lagar/Lagar/Svenskforfattningssamling/Skollag-2010800_sfs-2010-800/.. Accessed 7 January 2015.

SFS 2007:1349. Förordningen om försöksverksamhet med gymnasial lärlingsutbildning. (The ordinance for the upper secondary apprenticeship trial activity). The Swedish Parliament's website: http://www.riksdagen.se/sv/Dokument-Lagar/Lagar/Svenskforfattningssamling/Forordning-20071349-om-fors_sfs-2007-1349/. Accessed 7 January 2015.

SFS 2010:2039. Gymnasieförordningen. (The upper secondary school ordinance). The Swedish Parliament's website: http://www.riksdagen.se/sv/Dokument- 
Lagar/Lagar/Svenskforfattningssamling/Gymnasieforordning-20102039_sfs2010-2039/. Accessed 7 January 2015.

SFS 2014:421. Lag om gymnasial lärlingsanställning. (The upper secondary apprenticeship employment act). The Swedish Parliament's website: http://www.riksdagen.se/sv/Dokument-Lagar/Lagar/Svenskforfattningssamling/Lag-2014421-om-gymnasial-la_sfs-2014-421/?bet=2014:42. Accessed 7 January 2015.

SOU 2011:72. Gymnasial lärlingsutbildning med fokus på kvalitet - Hur stärker vi kvaliteten i den gymnasiala lärlingsutbildningen. (Quality in upper secondary apprenticeships - How can we raise the quality in the upper secondary apprenticeship model?) Regeringskansliet. Stockholm: Fritzes.

SOU 2010:19. Lärling en bro mellan skola och arbetsliv. (Apprenticeships a bridge between school and work). Stockholm: Fritzes.

SOU 2008:27. Framtidsvägen - en reformerad gymnasieskola. (The future pathway - A reformed upper secondary school). Stockholm:Fritzes.

Steedman, H. (2012). Overview of apprenticeship systems and issues. ILO contribution to the G20 Task Force on Employment. The International Labour Organisation's website: http://www.ilo.org/wcmsp5/groups/public/---ed_emp/---ifp_skills/documents/genericdo cument/wcms_190188.pdf. Accessed 7 January 2015.

Svenskt Näringsliv. (2008). Remissyttrande betänkandet Framtidsvägen, SOU 2008:27. Referral response 1. SN D.nr. 119/2008. Stockholm: The Confederation of Swedish Enterprise.

Svenskt Näringsliv. (2010). Remissyttrande. Lärling - en bro mellan skola och arbetsliv.SOU 2010:19. Referral response 2. SN D.nr. 190/2010. Stockholm: The Confederation of Swedish Enterprise.

Tanggaard, L. (2007). Learning at trade vocational school and learning at work: boundary crossing in apprentices' every day life. Journal of Education and Work, 20 (5), 453-466.

Wenger, E. (1998). Communities of practice. Learning, meaning and identity. Cambridge: Cambridge University Press. 
